\title{
The zone of non-being: When belonging becomes more important than being
}

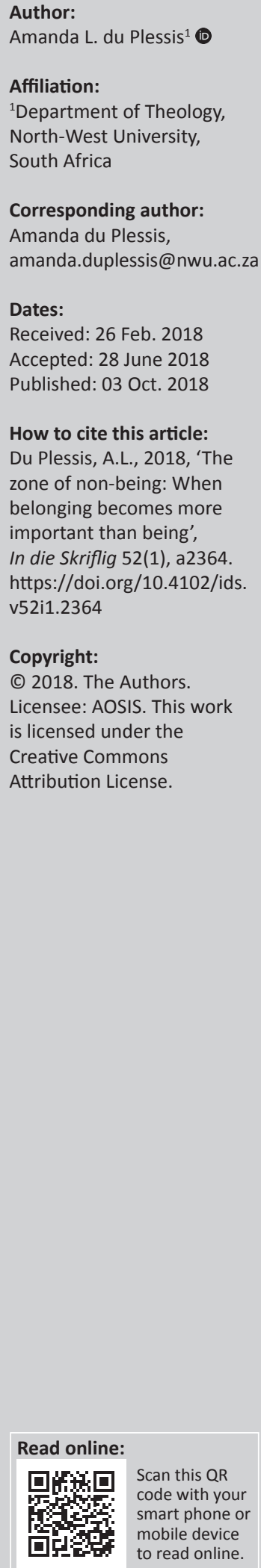

\begin{abstract}
Silent screams echo in South Africa, objecting to violence due to cultural and gender differences. Bitterness and anger increase as the cultures, knowledge systems and ways of being or 'nonbeing' are despised, demonised and declared substandard and irrational or even eliminated. Most of these individuals cannot afford to speak up, because belonging has become more important than being. It is inevitable that people would question their personhood and dignity when they find themselves in the space of intersection between culture, gender and violence. If the meaning of formosus is to bring out the beauty of each person, how is it that 'non-being' for some is better than being? In the fable of Hyginus, an alternative word for 'being' is 'care'. Human beings' existence is essentially dependent on care. The intersection between culture, gender and violence probes for the reformation of practical theological anthropology and, especially, a rethinking of the ministry of compassion. This article seeks to explore hermeneutics of renewal. The focus is on restoring and reforming the human being which can help nonbeings to express their deepest quest for personhood and dignity. In this sense, dignity is defined as being one with all the multiplicities, systems and paradoxes of one's own way of being, doing and knowing. The epistemology is from a pastoral care point of view.
\end{abstract}

\section{Introduction}

Culture, gender and violence are recurring themes worldwide - often in a negative sense. The differences among human beings, based on these aspects, can (and have been) used either to build or to destroy relationships. It is in the intersection between these aspects where challenges are created that must be dealt with and thereby necessitating continuous discourse. The human dilemma of displacement - with the inherent paradox of being connected to the world and yet feeling or being alone - is one example of a challenge that arises in the intersection between these aspects. Displacement often becomes the space and place were belonging is more important than being - a zone of non-being. When a person finds him- or herself in a zone of non-being, one's personhood and dignity are questioned. This article seeks to explore the hermeneutics of renewal which is aimed at restoring and reforming human being. This can help non-beings to express their deepest quest for personhood and dignity. The epistemology is from a pastoral care point of view to further explore the consequent challenges posed to the Christian church in general. The main aim of the article is to make a contribution to theory formation in pastoral caregiving within the global human dilemma of displacement by applying the methodology of hermeneutics. Questions that arise include: How should the church respond to the human dilemma of displacement? What are the pastoral care implications for helping the stranger, the homeless or the so-called nonbeings? What are the implications for contextualisation of pastoral care in an intercultural context? To be able to answer these questions, the article will unfold as follows:

- cultural intelligence or cultural quotient (CQ);

- christian understanding of formation, transformation and anthropology;

- from divine definition to divine infinition;

- being and belonging.

\section{Cultural intelligence or cultural quotient}

Until 2000 Africa Refugee Day was celebrated on 20 June; thereafter, the day became known as World Refugee Day. On this day, people are reminded that thousands of their fellow human beings are internally displaced refugees or refugees living in foreign countries because of circumstances beyond their control. Human displacement is real and not a new occurrence. According to Louw (2017a:2), the refugee dilemma and migrant crisis have become a global, civil and political nightmare because of violent behaviour associated herewith. Migration is being uprooted without a sense of belongingness. It seems as if a kind of global paranoia arises. On the 
one hand, citizens fear the incoming stranger and respond with distrust, fear and prejudice; on the other hand, guilt develops about what their reaction and behaviour towards other human beings ought to be. Human displacement also proposes a challenge to cultural characteristics, because barriers between cultures cause cultural distance.

Hofstede (1980:21) defines culture as the collective programming of the mind which distinguishes the members of one group from another'. The Latin word colo means to nurse, take care of or to transform the earth through work in order to live. Because human beings are embedded in a certain culture, it is likely that they will experience some kind of internal conflict when they are exposed to a different or unfamiliar culture. Cultural quotient (CQ) is defined as a human being's sensitivity to cultural differences, cultural empathy, ability to withstand the initial cultural shock, and the ability to cope with and adapt to foreign environments (Baalbaki 2015:7).

Yunlu, Clapp-Smith and Shaffer (2017:237) define cultural intelligence as 'a person's capability to adapt effectively to new cultural contexts' and it is 'a form of situated intelligence where intelligently adaptive behaviours are culturally bound to the values and beliefs of a given society or culture'. It therefore represents an important cross-cultural competence which is a crucial implication for pastoral care to the displaced human being. Yunlu et al. (2017:237) explain that CQ comprises four dimensions (Table 1):

People with a higher CQ can more easily navigate and understand different cultures and are therefore more likely to succeed when working in a different culture than their own. Apart from this, Edwards (2016:211) warns that both helping professionals and society at large have a long way to go to gain complete cultural competence. Pastoral caregiving, which aims to be respectful in helping displaced human beings with cultural differences, needs a new framework. Louw (2017b) stresses this importance by commenting that:

the current discourse in many practical theological circles and societies is how to address the quest for an intercultural approach in theory formation and to create ecclesial spaces for mutual exchange of positive life values that can enhance experiences of human dignity. (p. 5)

In his book Pastoral theology in an intercultural world, Lartey (2006:42) remarks that displaced human beings are increasingly being recognised as 'sources of authentic and

TABLE 1: The four dimensions of cultural quotient.

\begin{tabular}{ll}
\hline Cultural quotient & Meaning \\
\hline Metacognitive CQ & $\begin{array}{l}\text { A human being's ability to recognise and understand new } \\
\text { cultural information and integrate that information as } \\
\text { working knowledge (control of cognition/understanding). }\end{array}$ \\
Cognitive CQ & $\begin{array}{l}\text { A human being's cultural knowledge about different cultures } \\
\text { (existing knowledge structures). }\end{array}$ \\
Motivational CQ & $\begin{array}{l}\text { A human being's intrinsic interest and self-efficacy in } \\
\text { adapting to different cultures (ability to direct and sustain } \\
\text { energy on a particular task or a situation). }\end{array}$ \\
Behavioural CQ & $\begin{array}{l}\text { A human being's ability to utilise culturally sensitive behaviour } \\
\text { when interacting with people from a different culture } \\
\text { (outward manifestations and reactions of an individual). }\end{array}$ \\
\hline CQ, cultural quotient. &
\end{tabular}

crucial knowledge'. This recognition is vital in helping nonbeings overcome their fear and uncertainty in the process of wholeness which is aimed at restoring and reforming human dignity and personhood. In the pastoral care ministry, cultural intelligence is to respond respectfully and effectively to people of all cultures in a manner that recognises, affirms and values the worth of the other (Edwards 2016:212).

Cultural intelligence has a biblical mandate with the command to treat foreigners with respect and not to oppress or mistreat them (Ex 22:21). Smith (2013:86) indicates that Christ's death and resurrection have made it possible for believers to, once again, take up their creational calling to be culture makers, re-equipped for the task given to humanity at creation. Christ also set the example that in a fallen, broken world, the shape of that vocation is cruciform meaning that being cultural agents of the crucified God is not a project of triumphal transformation, but of suffering witness. To be a suffering witness is to sometimes (or more often) act differently than the generally accepted norm of everyday (Rm 12:1-2). Louw (2017:1) states that daily life for many poor people and migrants all over the globe is not automatically homely and includes a message of 'I don't belong here'. The challenge for the church is to enter the zone of non-being and create a new zone of acceptance where oppressive power categories cannot exploit them. It is about cruciform love in the mode of service, a calling, a vocation or a task given to believers by God at creation - to do culture.

Perez-Forster, Moskowitz and Javier (1996) state that:

what moves people to do what they do, or how one defines the idea of self in the context of the world, are intrinsically enmeshed with how a culture view the living process. (p. xiii)

In the African anthropology the cultural view of the living process is known as Ubuntu. Ubuntu is a philosophy that says we must care for others, because I am what I am because of who we all are. It defines humanity and indicates that human beings are all interconnected. For believers, the Hebrew word hesed ${ }^{1}$ is almost similar to Ubuntu. Hesed describes the nature of God (Ex 34:6-7) and is a quality that moves believers to act for the benefit of someone else without considering 'what is in it for me?' (Anon. 2010). The great commandment of God towards believers is to be present or involved in the lives of others - even those who are culturally different - to live a life of hesed and Ubuntu towards them. In Calvin's commentary The four last books of Moses (1852:61), the concept of a believer's attitude towards strangers (Ex 22:21; Lv 19:33-34) is described as:

Moreover, it must be observed that ... they are commanded to love strangers and foreigners as themselves. Hence it appears that the name of neighbour is not confined to our kindred, or such other persons with whom we are nearly connected, but extends to the whole human race; as Christ shows in the person

1.Hesed is difficult to translate, because it encloses a cluster of ideas - love, mercy grace, kindness, et cetera. It wraps up in itself all the positive attributes of God (Anon. 2010). 
of the Samaritan, who had compassion on an unknown man, and performed towards him the duties of humanity neglected by a Jew, and even a Levite. (Lk 10:30)

The command to believers is thus, as Smith (2013:86) articulates, a biblical theology of culture as a creational task. It explains that being God's image bearers is not a static property of being human, but a calling, a vocation and a task. Jesus Christ has imaged what it means to be God's viceregents: He has shown what it looks like to do this. Therefore, culture is not a noun (something out there), but a verb (something we do).

Doing (or creating) culture starts on a practical level - it should become life care; thus, practical theology as life care fides quaerens vivendi. Esperandio (2008:93) says that one of the greatest challenges to pastoral care is helping to distinguish the strategies that limit the process of creation, and make observable the dangers of imprisoning subjectivity causing pain and several pathologies. The fable of Hyginus ${ }^{2}$ might be an inspiration for pastoral caregivers, as it shows that a human being's existence is essentially dependent on care. Eventually, only care can sustain the existence and transformation of non-beings to being in creating space or a home for the homeless where being is more important than belonging. The first challenge then for the pastoral caregiving ministry of the church is to be there with the non-beings where they are - and to listen to them. To listen to their stories give, first and foremost, a message of 'you are important' - a message opposite of what they receive in the zone of non-being. Being there is the first key element in developing cross-cultural competence to reach out to the displaced person.

The book of Deuteronomy is one of the richest books in reference to the displaced person. The Hebrew Bible has 36 commands to 'love the stranger' and only two to 'love your neighbour'. The understanding of these references is firstly, the stranger is associated with the name of God (Dt 16:11). Secondly, the stranger is invariably linked with allusions to orphans and widows - vulnerable and defenceless people (Dt 27:19). Thirdly, the advent of the stranger calls for a 'justice' that seems to go beyond normal agreements of homeland security (Dt 27:19; Kearney 2010:21).

According to Müller (1996:31), the best approach to crosscultural pastoral caregiving is the narrative approach which calls for a position of a conversational questioning that leaves room for the other person's story as told by themselves in their own words, unchallenged by preconceived therapeutic

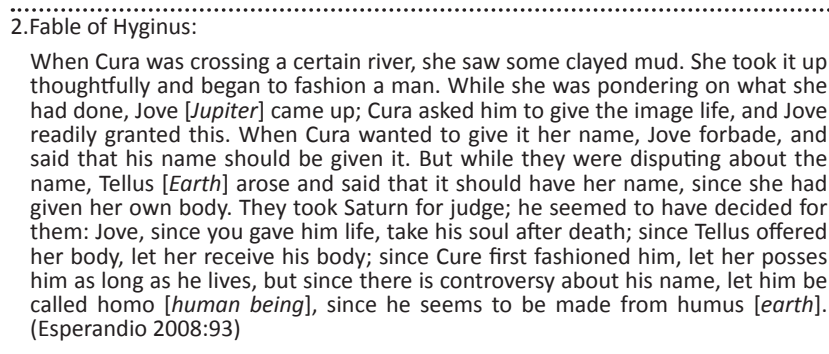

When Cura was crossing a certain river, she saw some clayed mud. She took it up thoughtfully and began to fashion a man. While she was pondering on what she had done, Jove [Jupiter] came up; Cura asked him to give the image life, and Jove readily granted this. When Cura wanted to give it her name, Jove forbade, and said that his name should be given it. But while they were disputing about the said that his name should be given it. But while they were disputing about the name, Tellus [Earth] arose and said that it should have her name, since she had given her own body. They took Saturn for judge; he seemed to have decided fo them: Jove, since you gave him life, take his soul after death; since Tellus offered her body, let her receive his body; since Cure first fashioned him, let her posse him as long as he lives, but since there is controversy about his name, let him be called homo [human being], since he seems to be made from humus [earth]. (Esperandio 2008:93)

knowledge. Cultural intelligence includes an attitude of adopting the position of a servant (Phlp 2:25) and a not knowing stance where the involved parties work together in mutual co-authoring of a new story where human dignity and personhood are restored.

Falicov (1995:375) mentions an important aspect when working across cultural borders. He proposes that a cultural borderland is created in the overlapping zones of differences or similarities between different cultures. The borderland gives rise to internal inconsistencies and conflict, but at the same time offers possibilities of connectedness. He stresses that change or healing is the result of the encounter, contact and interaction, and not of programmes of education or social engineering. A mutual understanding and respect will be the result when we connect on cognitive and affective levels. Cultural intelligence asks for a willingness to listen and to be drawn into the stories and lives of others, because only then will new worlds of understanding emerge.

In academic research the participation and action-oriented research methodology, combined with a narrative approach, seems to be a workable methodology in pastoral care with cross-cultural displaced individuals. Participation and action-oriented research recognises the fact that a single person cannot necessarily have all the knowledge and skills needed for the best solution. Research, firstly about the different facets of the situation, and secondly about the particular person that might be best equipped to deal with the specific situation, forms an essential part of the methodology. Because participation and action-oriented research takes the people experiencing the problem as well as their culture or situation into account, one can never simply accept one solution as being applicable to all situations (Du Plessis \& Breed 2013:7).

From the above discussion, one key element of importance for pastoral care to the cross-cultural displaced person arises, namely be with.

\section{Christian understanding of formation, transformation and anthropology}

In our thinking regarding restoring or renewing the notion of personhood and human dignity, it is important to look at Christian anthropology and Christian understanding of formation and transformation. The Harper's Bible dictionary (Achtemeier 1985) defines formation as:

The action or process of forming; a putting or coming into the form. It refers to the manner in which things are formed with respect to the disposition of its parts; formal structure, confirmation. (p. 990)

The Latin word formosus means to bring out the beauty. The same meaning is conveyed in Paul's words in Galatians 4:19 when he writes that Christ must be formed in believers. The inner being of believers are altered in such a way that they 
are no longer the same, but are transformed to the image of Jesus Christ. It is a process that takes place and the end is in contrast with what used to be.

Naidoo (2012) gives a good description of a Christian understanding on formation:

The Christian theological origins of the idea of formation are in God's creative work: the One who is formless (Deut. 4:12, 15) forms from a formless void (Ge. 1:2), creating, giving-life, shaping (Is. 45:7; Jer. 1:5; Ge. 2:7-8) and ordering, through a moral order of the Torah and through Christ, the model of perfect humanity. Formation is a life-long process of becoming, of being formed and develop in the likeness of Christ (Col. 1:28; Ro. 12:2). It is personal and relational formation which seeks to promote encounters and cooperation with God and society as a whole. (p. 3)

If we look at the meaning of the Latin word colo [to nurse, take care of or to transform the earth through work in order to live], we realise that God was doing culture when he created. The believer's creational calling of culture makers thus has the meaning of bringing out the beauty in ourselves and then helping others in restoring their personhood and human dignity. The aim of pastoral care is to lead another to wholeness, namely the development of Christ's character within the context of the church as the body of Christ.

According to Vorster (2015:165) human beings cannot truly know themselves 'if they do not know the ground of their being and the origin of their existence'. He based this view on the link Calvin made between knowledge of ourselves and knowledge of God. When the essential relationship between God and believers is ignored, people will have a distorted knowledge about their personhood and dignity, resulting in sinful pride and behaviour. For Calvin, a person can be understood only in relation with God (Vorster 2015:164). The basic anthropology of Calvin is that human beings exist in God through the grace of God to heighten the glory of God. In his explanation that human beings are created to be image bearers of God, Calvin differentiates between a 'picture image' and a 'mirror image'. He explains that human beings are not a static lifeless picture image of God, but a living mirror image, because the 'human being represents God's majesty in being endued with reason and understanding and having the ability to distinguish between good and evil' (Vorster 2015:171). Based on his exegesis of Colossians 3:10 and Ephesians 4:24, Calvin recognises knowledge, righteousness and goodness as the central qualities of God that believers ought to reflect; yet he does not limit the reflection to these characteristics. The distinction between a 'picture image' and a 'mirror image' is essential in the understanding that to reflect the image of God is an action or process of forming. This can be described in theology as the beautification of life (fides quaerens beatitudinem).

In Bonhoeffer's anthropology, he emphasises the communal character of humanity (Koopman 2014:992) by indicating that a human being exists only through other human beings.
Bonhoeffer first based his relational anthropology on the image of God and explained that it refers to the freedom of human beings, but says that freedom is a relationship. Just as Jesus Christ gives himself to us, we ought to live in communion with others. It is thus not a freedom from other human beings, but a freedom for other human beings and it implies sacrifice. Bonhoeffer adapts an ethos of interpathy, meaning that he could think with, feel with and eventually identify with people from other cultures. Koopman (2014) concludes that Bonhoeffer's anthropology teaches people lessons about life together:

We learn that life together can be contaminated and hindered by sin. We learn that the work of Jesus Christ is sufficient for life together. We learn that life together is a gift of the triune God. We learn about the indispensable role of the church as the place where Christ is manifested today, in this quest for life together. We learn that life together is a life in search of the actualization of dignity and unity, reconciliation and justice, freedom and peace. One important skill for life together would, therefore, be to remember and drink from these Trinitarian, Christological, soteriological and ecclesiological wells for life together. (p. 995)

The lessons for life together - living together with other human beings in mutual understanding and respect - are again an action or process of forming or culture-making when believers create a safe space, place or zone of being in the renewal of personhood and human dignity. Kearney (2010:19) states through the Christian history that it is evident that the decision for hospitality over hostility is never made once and for all; it is a wager that needs to be renewed again and again.

The following key elements are of importance from the above discussion: feel with and think with.

\section{From divine definition to divine infinition}

Three key elements that were identified thus far in the article are be with, feel with and think with. These three elements answer to the metacognitive, cognitive and motivational dimensions of cultural intelligence. The fourth dimension is behavioural cultural intelligence and can be seen in the paradigm shift from divine definition to divine infinition. Louw (2017b) describes this paradigm shift as a:

move from a fixed dogmatic approach to a more flexible dynamics of hermeneutics within different cultural contexts; i.e. the dynamics of 'precensing'; a position of 'not knowing' and being open for the mystery and surprise of God's intervention from the 'eschaton' into the vulnerability of the existential here and now of daily events. (p. 11)

The issue at hand is how God is perceived - a metaphysical immutable God or a compassionate sustainable God who still intervene on the basis of his convent love hesed. Louw (2017b:11) accentuates that in Old Testament studies, the concept God is more verb-like, than noun-like. In Exodus 
3:14, YHWH has the form of a verb, indicating the sustainable continued presence or intervention of God. Thus, God is acting, forming or transforming, or creating divine intervention through and by the Holy Spirit within the actions of the church as expressions of God's presence in the world. Schipani (2008) writes:

Counselling that is truly pastoral occurs not only in a safe therapeutic place, but also in a sacred place where the presence and activity of the Holy Spirit is acknowledged (at least by the counsellor). (p. 107)

The zone of non-being can (and must) be a sacred place where the presence and activity of the Holy Spirit become evident in the care of the other, the stranger or the non-being. Louw (2017b:11) concludes that the name of God refers more to a 'verb in the continuous tense, than a fixed substance in the past tense'. This has the implication of a paradigm shift from divine definition to define infinition, or as Louw describes it, 'a theological paradigm shift from the omniscience of God to the infiniscience of God'. God is acting through the Holy Spirit within the functions of the church infinito: compassionate on-going life care.

The well-known teaching of Jesus in Matthew 25:31-46 about the sheep and the goats is an example of what this change in thinking looks like. In the past, the structural churches mainly focused on divine definition and the preaching centred on the theme of who and why God is. Divine infinition asks the questions 'how is God?' and 'where to?', and aims to transform the zone of non-being into ecclesiastical spaces where non-beings can receive care. Calvin's comments on this pericope of Matthew (1854) entails the following:

The sum of what is said is, that believers, in order to encourage themselves to a holy and upright conduct, ought to contemplate with the eyes of faith the heavenly life, which, though it is now concealed, will at length be manifested at the last coming of Christ ... Christ does not here specify everything that belongs to a pious and holy life, but only, by way of example, refers to some of the duties of charity, by which we give evidence that we fear God. For though the worship of God is more important than charity towards men, and though, in like manner, faith and supplication are more valuable than alms, yet Christ had good reasons for bringing forward those evidences of true righteousness which are more obvious. ... Christ does not make the chief part of righteousness to consist in alms, but, by means of what may be called more evident signs, shows what it is to live a holy and righteous life; as unquestionably believers not only profess with the mouth, but prove by actual performances, that they serve God... We must be prodigiously sluggish, if compassion be not drawn from our bowels by this statement, that Christ is either neglected or honoured in the person of those who need our assistance. So then, whenever we are reluctant to assist the poor, let us place before our eyes the Son of God, to whom it would be base sacrilege to refuse anything ... He likewise shows that he acknowledges those acts of kindness which have been performed gratuitously, and without any expectation of a reward. (pp. 80-84)

The fourth key element is to act: Jesus Christ showed believers what it looks like to do this as Smith (2013:86) indicates. If we do not act, we are looking 'up not down, obsessed by some fantasy in the skies rather than heeding a flesh and blood presence here on earth' (Kearney 2010:29). It is a demonstration of love and an unqualified involvement or commitment to others based on love and fear for God. Love of the displaced person becomes love of God. Divine infinition encompasses a theology of compassion, a community of believers, inclusiveness and to bring meaning to life. Matthew 25 is also an example where everyday life becomes the object for practical theology: pastoral care is the continuation of the proclamation of the Word and therefore the love commandment in a practical manner. The meaning is this: the divine, as refugee, is in each individual who asks to be received in our midst. The face that serves as trace of transcendent divinity is also a portal to humanity in flesh and blood immanence (Kearney 2010:20). Lama, Tutu and Abrams (2016) write about the paradox, which is found in the countering of injustice and inequality, by explaining that the:

more we heal our own pain, the more we can heal the pain of others, but the way we heal our pain is actually by turning to the pain of others. (p. 70)

It is a virtuous cycle which best finds relevance in the good news of the gospel.

Although God is omnipresent, divine infinition means to make God present in the pain of others by being there, feeling and thinking with them and then acting according to our belief. Cultural intelligence also involves the necessity of the contextualisation of pastoral care. Contextualisation is an attempt to understand the Christian faith in terms of a particular context through the recognition of the present human experience (Bevans 2016:3). The incarnational nature of Christianity is important in divine infinition, because 'Christianity, if it is to be faithful to its deepest roots and to its most basic insights, must continue God's incarnation in Jesus by becoming contextual' (Bevans 2016:12). Believers make God present by being present among human beings. Although the revelation of God is understood as being complete in an objective sense, God's revealing action is also seen as an on-going process through the lives of believers. God cannot be revealed primarily in concepts or ideas, but rather through action in concreate reality.

When we think about 'action in concrete reality', we must remember that theology is a wider activity than only scholarship and that various cultures have preferred ways of articulating their faith through, for example art, hymns, storytelling, drama and cinema. In other words, the rituals, symbols and metaphors that are used, conceive theology in terms of expressing one's present experience with regards to one's faith (Bevans 2016:20). Schweitzer (2001) pleads for hermeneutics of :

... renewal and completion which aims at restoring and reforming human expressivity, which helps people not only to express their deepest quest for human dignity and meaning. It is 
my conviction that such a movement can help a practical theology to start a dream - to reshape the social and living environment and to transform land into a place of hope and enjoyment. (p. 14)

Human expressivity is thus attempts to produce works of art that articulate faith understandings in a non-verbal way. Divine infinition via the actions or behaviour of believers do not always need to be verbal; sometimes (or more often in the dilemma of human displacement) actions speak louder than words. Care for human beings - the other, the stranger or the non-being - implies action. Care is in fact a verb.

The following key elements arose from this part: to act in the context of belief.

\section{Being and belonging}

The human dilemma of displacement has an inherent paradox of being connected to the world and yet feeling or being alone. Due to the various reasons such as xenophobia, the struggle between integration and segregation, displacement often becomes the space and place where it is more important for human beings to belong than to be. It is as if these migrants or refugees create a zone of non-being where their identity is suppressed or denied in order to survive. The Latin word identitas means 'the same' or 'identical'. There are different kinds of identity, for instance cultural identity, gender identity, religious identity. These are basically an indication of a common element that binds a group together. The problem is that such elements not only seem to divide human beings, but they are rather fragile and not enough to shape present-day identity. The division in different groups erects more barriers between human beings, leading to feelings of distrust, fear and roots of prejudice for the other: the stranger or the unknown.

The Dalai Lama (Lama et al. 2016:74) made the comment that since he has become a refugee, he was liberated and stripped of formality which made him become much closer to reality. If this is true, we can conclude that different groups of identity actually deprive human beings from their most basic all-inclusive identity, namely being human (humanity). Esperandio (2008:90) writes about a typical identity trap to believe in the existence of an 'ideal' identity, because it places humanity in different classes based on higher and lower value. Another identity trap is that of capitalistic standard identity where discrimination against the poor is evident (cf. Ja 2). Identity superiority or identity inferiority is in direct disobedience to the love commandment and the value of the image of God in every human being. Cultural intelligence pastoral care recognises God's creation of variety and a diverse world. Human beings were created in God's image (Gn 1:26-27) and he pronounced human beings as 'very $\operatorname{good}^{\prime}$ (v. 31).

Therefore, all identity groups have the same status, dignity and worth that result in bearing the image of God (Smith 2011:506). To my mind, every spiritual and psychological disorder and emotional pain that people experience is the result of denying a human being's identity, dignity or value in Christ - either by themselves or by others. What is experienced as a life crisis often pertains to a lack of understanding of identity and meaning of life. When displaced human beings find themselves in a zone of nonbeing, their identity, dignity or worth is denied by others and eventually by themselves. Group identity is connected to a certain place of origin, or to a group or institution one belongs to and therefore displaced human beings immediately lose their group identity when they are uprooted from the known. They become a non-being in an attempt to belong and to fit in the new space and place. As time passes they will adopt the identity of the new place or zone or group. A group identity can thus change and are dependent on circumstances. Personal identity cannot be changed so quickly, because it is deeply rooted in a person's view of themselves, of God, other human beings, the world, and how they fit in in these relationships. Personal identity is formed from birth right through our life and is deeply rooted into the subconscious. It can only change when deep inner change take place through repentance.

Vorster (2013:9) cites Jönsson who indicated that the imago Dei is set in the Old Testament as the point of departure for human beings' relationships. The doctrine of the image of God forms the theological groundwork for believers' understanding and actions towards other human beings. Vorster (2013:9) proposes that the concept of human dignity is the remedy for social ills such as the displacement of human beings, and that the church 'should be deeply involved in equipping the community to adopt this idea as the foundation of all human relations'. Believers - as a living mirror image - should become the protectors of human dignity by becoming involved in the lives of non-beings via support, guidance and advocacy. The church must be a prophetic voice against evil. Schipani (2008:96) describes Christian caring as having a particular vision of reality and the good, as a disposition of care as a form of love towards other human beings who are inspired by Jesus Christ, and as a certain sense of vocation to serve in partnership with the Holy Spirit.

Human beings who find themselves in a zone of non-being have lost hope. Through care, believers can plant seeds of hope that can anticipate something new for change and transformation in order to set new goals for meaningful future orientation. Hope is a creative energy that can play a decisive role in the (trans)formation of culture which can change the zone of non-being into a hospitable place of peaceful co-existence and cohabitation. True hope does not focus on merely the part (the individual), but rather on the whole (God's plan for the universe) (MacArthur \& Mack 1994:195). In the same way, identity is not something individual, but is built on relationships - personal identity cannot be built apart from a social identity. Identity is therefore the need for an ecclesiology of trust and respect to create a safe place for being. To be loved and to belong is every human being's most fundamental inner need. Identity formation is based on the fulfilling of these needs. 
God's command to the church is to lead human beings to wholeness (the development of character within the context of the church as the body of Christ). Naidoo (2012:4) describes this process as follows: firstly, apprenticeship of spiritual or character formation through theological knowledge, pastoral skills and spiritual formation; secondly, cognitive or intellectual apprenticeship through supporting and guidance in preparation for work, the development of critical thinking, and on-going and creative learning; and thirdly, practical apprenticeship of skills formation through skills development and understanding, responsibility with confidence and authority, openness and humility. Louw (2012:117) adds a fourth dimension: physical and natural dimension (ecology) through corporate responsibility which is extended to creation as a whole, because the healing of individuals cannot be separated in a dualistic way from nature. For Louw (2012:120) cura animarum must be supplemented by cura terrea [care for the land, environment and ecology]. At the end, liberation and healing will be part of all the dimensions in the life of human beings which is the meaning of the biblical word Shalom.

Louw (2012:127) cites Clinebell and states that ecology (land) plays a vital role in wholeness, because the possession of land is a deeply spiritual aspect based on the covenant relationship with God. Land is the space for human living which must be governed by principles of justice, hospitality and integrity (Ps 137:16-18). Land possession is constituted by three theological indicators, namely promise, gift and grace. Therefore, the church has the duty to speak against economic exploitation - it is a moral issue that should be condemned.

\section{Conclusion}

Klein (2015:24) writes: 'Let's begin with the obvious: there are no easy answers in the Middle East.' This is true not only in the Middle East, but also for the whole world. Much has been written and much will be written in attempts to formulate possible solutions. The role of the church, and especially of practical theology, is to be 'salt and light of the world' (Mt 5:13-16). History has shown that not everybody will respond to the gospel, but those who do respond will experience life renewal and transformation. Cross-cultural pastoral care to displaced human beings who find themselves in a zone of non-being is based on four key elements that were identified in this article, namely be with, feel with, think with and act with, based on our belief. Eventually, the roots for these elements stem from believers creational calling. These elements will allow pastoral caregivers to continue the proclamation of the Word, but in a practical manner. The cliché of 'I don't care what you know until I know how much you care' seems to be true and relevant in the dilemma of human displacement. Care was also been identified as a verb, an action or behaviour. To care is to formulate culture and, as image bearers of God, believers have the vocation to care.

\section{Acknowledgements Competing interests}

The author declares that she has no financial or personal relationships which may have inappropriately influenced her in writing this article.

\section{References}

Achtemeier, P.J. (ed.), 1985, Harper's Bible dictionary, Harper \& Row, San Fransisco, CA. Anon., 2010, Discover the word, viewed 03 January 2018, from https:// discovertheword.org

Baalbaki, S., 2015, 'Cross-cultural quotient', Journal of International Diversity 3(1), $2-34$.

Bevans, S.B., 2016, Models of contextual theology, Orbis Books, Maryknoll, NY.

Calvin, J., 1852, Commentaries on the four last books of Moses by John Calvin, vol. 3, transl. C.W. Bingham, Printed for the Calvin Translation Society, T. Constable.

Calvin, J., 1854, Commentary on a harmony of the evangelists, Matthew, Mark and Luke, vol. 3, transl. W. Pringle, Printed for the Calvin Translation Society, T. Constable.

Du Plessis, A.L. \& Breed, G., 2013, 'A possible solution for corruption in South Africa with the church as initiator: A practical theological approach', HTS Theological Studies 69(2), 1-10. https://doi.org/10.4102/hts.v69i2.1298

Edwards, J.B., 2016, 'Cultural intelligence for clinical social work practice', Clinical Social Work Journal 44(1), 211-220. https://doi.org/10.1007/s10615-0150543-4

Esperandio, M.R.G., 2008, 'Identity and care in times of change: Is the idea of identity meaningful for pastoral care and counselling?', in K. Federschmidt \& D.J. Louw (eds.), Intercultural and interreligious pastoral caregiving: The SIPCC 1995-2015, 20 years of international practice and reflection, pp. 85-93, Books of Demand $\mathrm{GmbH}$, Norderstedt, Düsseldorf.

Falicov, C.J., 1995, 'Training to think culturally: A multidimensional comparative framework', Family Process 34(1), 373-388. https://doi.org/10.1111/j.15455300.1995.00373.x

Hofstede, G., 1980, Culture's consequences: International differences in work related values, Sage, Beverly Hills, CA.

Kearney, R., 2010, Anatheism: returning to God after God, Columbia University Press, New York.

Klein, J., 2015, 'As chaos grows in Syria, Iran could be a surprising American ally', Time, Special Report, Exodus. The epic migration to Europe \& what lies ahead, 19 October, pp. 24-25.

Koopman, N., 2014, 'Bonhoeffer and the future of public theology in South Africa: The on-going quest for life together', NGTT 55(1), 985-998.

Lama, D., Tutu, D. \& Abrams, D., 2016, The book of joy, Penguin Random House, New York.

Lartey, E., 2006, Pastoral theology in an intercultural world, Epworth, Werrington.

Louw, D.J., 2012, 'Cura animarum, cura terrae and eco-spirituality: Towards an aesthetics of humility in an eschatological approach to land, nature and environment', in K. Federschmidt \& D.J. Louw (eds.), Intercultural and interreligious pastoral caregiving: The SIPCC 1995-2015, 20 years of international practice and reflection, pp. 117-138, Books of Demand GmbH, Norderstedt, Düsseldorf.

Louw, D.J., 2017a, 'Ekhaya: Human displacement and the yearning for familia homecoming: From Throne (Cathedra) to Home (Oikos) in a grassroots ecclesiology of place and space: Fides Quaerens Domum et Locum [Faith seeking home and space]', HTS Theological Studies 73(4), 1-11. https://doi.org/10.4102/ hts.v73i4.4484

Louw, D.J., 2017b, 'Practical theology as life science: Fides Quaerens Vivendi and its connection to Hebrew thinking (Hālak)', In die Skriflig 51(1), a2239. https://doi. org/10.4102/ids.v51i1.2239

MacArthur, J.F. \& Mack, W.A., 1994, Introduction to Biblical counseling, Word Publishing, Dallas, TX.

Müller, J., 1996, 'Intercultural exchange: A discovery of being different', in K. Federschmidt \& D.J. Louw (eds.), Intercultural and interreligious pastoral caregiving: The SIPCC 1995-2015, 20 years of international practice and reflection, pp. 27-36, Books of Demand GmbH, Norderstedt, Düsseldorf. Naidoo, M., 2012, Between the real and the ideal: Ministerial formation in South Africa churches. Unisa Press, Pretoria.

Perez-Forster, R.M., Moskowitz, M. \& Javier, R. (eds.), 1996, Reaching across boundaries of culture and class, Jason Aaronson, New York.

Schipani, D.S., 2008, 'Interfaith pastoral model: A wisdom model', in K. Federschmidt \& D.J. Louw (eds.), Intercultural and interreligious pastoral caregiving: The SIPCC 1995-2015, 20 years of international practice and reflection, pp. 94-108, Books of Demand $\mathrm{GmbH}$, Norderstedt, Düsseldorf.

Schweitzer, F., 2001, 'Creativity, Imagination and criticism: The expressive dimension in practical theology', in P. Ballard \& P. Couture (eds.), Creativity, imagination and criticism: The expressive dimension in practical theology, pp. 3-15, Cardiff Academic Press, Cardiff. 
Smith, J., 2011, 'Ethnicity', in T. Clinton \& R. Hawkins (eds.), The popular encyclopedia of Christian counseling, pp. 506, Harvest House Publishers, Eugene, OR.

Smith, J.K.A., 2013, Discipleship in the present tense, Calvin College Press, Grand Rapids, MI.

Vorster, J.M., 2013, 'Dealing with violence in South Africa: The ethical responsibility of churches', Scriptura 112(1), 1-15. https://doi.org/10.7833/112-0-56
Vorster, N., 2015, 'Calvin on the created structure of human nature: The influence of his anthropology on his theology', Journal of Theology for Southern Africa 151(1), 162-181.

Yunlu, D.G., Clapp-Smith, R. \& Shaffer, M., 2017, 'Understanding the role of cultural intelligence in individual creativity', Creativity Research Journal 29(3), 236-243. https://doi.org/10.1080/10400419.2017.1360070 